УДК 343.98:343.431(477)

DOI https://doi.org/10.32837/pyuv.v0i2(31).589

\author{
В. В. Коваленко \\ orcid.org/0000-0001-5310-2092 \\ кандидат юридичних наук, доиент, \\ професор кафедри крилінально-правових дисииплін \\ Луганського державного університету внутрішніх справ ілені Е. О. Дідоренка
}

\title{
ТИПОВІ СПОСОБИ, СЛІДИ Й ОБСТАНОВКА ВЧИНЕННЯ ЗЛОЧИНУ ЯК ЕЛЕМЕНТИ КРИМІНАЛІСТИЧНОЇ ХАРАКТЕРИСТИКИ ТОРГІВЛІ ЛЮДЬМИ
}

Постановка проблеми. Ст. 11 Закону України «Про протидію торгівлі людьми» визначає, що боротьба з торгівлею людьми є невід’ємною складовою частиною діяльності органів Національної поліції України по боротьбі зі злочинністю, які, зокрема, здійснюють заходи щодо виявлення фактів торгівлі людьми, осіб, котрі постраждали від торгівлі людьми, встановлення осіб - торговців людьми та притягнення їх до відповідальності шляхом реалізації організаційних, оперативно-розшукових, адміністративно-правових, процесуальних, аналітично-дослідницьких, інформаційних та інших заходів [1]. Утім, сьогодні значна кількість злочинів щодо торгівлі людьми залишаються нерозкритими, внаслідок чого багато злочинців уникають відповідальності за вчинення злочину, що потребує удосконалення відповідних криміналістичних рекомендацій щодо розслідування цього виду злочинів.

Аналіз останніх досліджень i публікацій. Проблеми елементного складу криміналістичної характеристики торгівлі людьми розглядали такі науковці, як А.І. Волкова, П.В. Горбасенко, Д.М. Бабак, О.В. Захарова, Н.С. Карпов, В.П. Корж, В.О. Малярова, М.С. Набруско, Л.П. Никифоряк, Т.А. Пазинич, В.М. Пащенко, О.В. Полуляхов, О.В. Пустова, В.В. Пясковський, P.М. Римарчук, О.В. Шаповал, М.П. Шруб, M.O. Яковенко та ін. Однак сьогодні такі елементи криміналістичної характеристики торгівлі людьми, як типові способи, сліди й обстановка вчинення злочину з урахуванням сучасної слідчо-судової практикипотребуютьпереосмисленняйуточнення.

Формулювання цілей. Метою статті є розкриття сутності таких елементів криміналістичної характеристики торгівлі людьми, як типові способи, сліди й обстановка вчинення злочину на основі узагальнення спеціальної літератури та практики досудового розслідування і судового провадження за фактами цього виду злочинів.

Виклад основного матеріалу. Відповідно до ч. 1 ст. 91 КПК України у кримінальному провадженні підлягають доказуванню: подія кримінального правопорушення (час, місце, спосіб та інші обставини вчинення кримінального правопорушення); обставини, які впливають на ступінь тяжкості вчиненого кримінального правопорушення, характеризують особу обвинуваченого, обтяжують чи пом'якшують покарання, виключають кримінальну відповідальність або є підставою для закриття кримінального провадження тощо [2]. Відомо, що спосіб учинення злочину (тобто дії злочинця, виражені в певній послідовній системі операцій і прийомів, що спрямовані на досягнення злочинної мети) охоплює спосіб готування, спосіб учинення, спосіб приховування (утаювання, знищення, фальсифікації інформації). Однак спосіб злочину не завжди має повну структуру. Існують злочини, які можуть вчинятися без попередньої підготовки або не мають за мету подальше приховування події або її слідів [3, с. 10].

Проведений нами аналіз матеріалів кримінальних проваджень за фактами торгівлі людьми, розслідуваних у 2016-2019 рр., свідчить про те, що у $84,6 \%$ випадків спосіб вчинення торгівлі людьми був повноструктурним (тобто у структурі способу вчинення наявні підготовка, вчинення і приховування), у решті випадків $(15,4 \%$ ) стадія підготовки або приховування злочину була відсутня.

Л.В. Черечукіна та М.О. Яковенко звертають увагу на те, що криміналістичне розуміння способу вчинення злочину значною мірою відрізняється від його кримінально-правового тлумачення. Насамперед це зумовлено розбіжністю об’єктів дослідження та спрямованістю завдань. I якщо знання способу вчинення торгівлі людьми у кримінально-правовому аспекті має важливе значення для правильної кваліфікації діяння, то з огляду на криміналістичний аспект пріоритетна роль належить ознакам способу вчинення злочину, які відбиваються у комплексі різноманітних матеріальних та ідеальних слідів. Саме це дозволяє правильно зорієнтуватися у вчиненому діянні та визначити найбільш оптимальні методи його розкриття [4, с. 21$]$.

Для типізації способів вчинення торгівлі людьми базовими є форми вчинення такого злочину, закріплені КК України. Перша форма злочину, передбаченого ст. 149 КК України, охоплюе дії з купівлі-продажу людини, що полягають у безповоротній передачі (отриманні) людини за грошову винагороду. 
Під здійсненням іншої незаконної угоди, об'єктом якої є людина, слід розуміти вчинення інших дій, не пов' язаних із купівлею-продажом людини, зокрема: передача людини в рахунок погашення боргу, в обмін на інші, крім грошей, цінності або послуги матеріального характеру, дарування, передача в оренду тощо [5, с. 13-14].

Способу вчинення торгівлі людьми зазвичай притаманна стадійність. 3 урахуванням природи злочину й об'єктивної закономірності його вчинення поетапно П.В. Горбасенко виокремлюе такі стадії торгівлі людьми: 1) підшукання жертви торгівлі, знарядь, засобів та інструментів майбутньої операції з нею, досягнення домовленості з контрагентами злочинної угоди про переміщення жертви й оплату її вартості; 2) умовляння або примушення жертви вчиняти певні дії або ухилятися від їх вчинення з метою полегшення вчинення злочину; 3) фізичне пересування жертви до замовника за чітко встановленим маршрутом в умовах максимальної конспірації; 4) експлуатація жертви, що $\epsilon$ найбільш тривалою та містить низку способів використання, придушення опору жертви, забезпечення контролю за її поведінкою. На кожній із цих стадій злочинці вдаються до різних способів, які є різними за характеристикою, ступенем криміналізації, часом тривалості [6, с. 9].

Досліджуючи практику розслідування таких злочинів, ми визначили такі типові етапи їх вчинення: 1) підшукання жертви $(92 \%) ; 2$ ) умовляння або примушування жертви $(100 \%) ; 3)$ переміщення жертви $(100 \%)$ і 4) експлуатація жертви $(15,4 \%)$. В абсолютній більшості вивчених випадків злочинна діяльність була припинена правоохоронцями на етапах вербування та переміщення жертв.

Щодо підготовки до вчинення злочину, то у $92,3 \%$ випадків злочинці підшукували жертву, у $56,2 \%$ випадків - підшукували спеціальні знаряддя та засоби (мобільні телефони, месенджери для зв'язку із жертвою та спільниками, транспортні засоби для транспортування жертви тощо), у 100\% на підготовчому етапі вчинення злочину досягали домовленості із контрагентом про укладання незаконної угоди щодо людини.

$\mathrm{У} 48,2 \%$ випадків злочинці підшукували жертв злочину в мережі інтернет (на сайтах знайомств, дошках оголошень, де пропонували роботу, в месенджерах); у $37,5 \%$ випадків - виходили на жертв через спільних знайомих, в т. ч. й через осіб, які раніше ставали жертвами торгівлі людьми; у $38 \%$ випадків - знайомилися із жертвами у публічних місцях (кафе, ресторанах, торгівельних центрах).

Щодо способу впливу на жертву, то злочинці найчастіше умовляли потерпілих, звертаючи увагу на їх уразливий стан, скрутне матеріальне становище й обіцяючи гарний заробіток за кордоном тощо.
Досить часто на жертву, окрім психологічного впливу та фізичного насильства, може чинитися й матеріальний вплив. Класичним прикладом матеріального впливу (який несе й елемент психічного тиску), на думку В.О. Малярової, є властиве для торгівлі людьми втягнення потерпілого в боргову кабалу. Тобто, попередньо штучно ввівши жертву в боргову залежність, злочинці надалі вимагають відшкодування боргу, єдиною можливістю відпрацювання якого є, наприклад, проституція. Реалізація такого способу починається ще на етапі втягнення, коли жертві пропонуються послуги з оплати всіх витрат із оформлення документів і переїзду за кордон. Оскільки потерпілі, які виїжджають за кордон у надії покращити свій матеріальний стан, зазвичай не мають необхідної суми для оплати поїздки, природно, що більшість із них погоджуються на таку «вигідну» пропозицію «фірми з працевлаштування» або фізичної особи [7, с. 109].

A.I. Волкова наводить такий перелік традиційних способів вербування для цієї сфери: оголошення, які пропонують роботу за кордоном, що не потребує високої кваліфікації (офіціантки, няні, домогосподарки); через друзів і знайомих, котрі користуються їхньою довірою; знайомство на дискотеці, у барі, де у приємній атмосфері пропонують посередницькі послуги у працевлаштуванні. Потенційні жертви - це переважно дівчата з бідних сімей, у багатьох немає батьків; «шлюбні агентства», іноді їх називають «наречені поштою», або міжнародні служби знайомств; туристичні фірми; система AU PAIR (au pair у перекладі з французької - «нянька») [8, с. 177].

Щодо способів приховування торгівлі людьми, то у $15,4 \%$ досліджених нами випадків злочинці використовували підроблені документи, у $30,8 \%$ - повідомляли вербованим особам неправдиві відомості про себе, у 77\% - використовували спеціально придбані одноразові мобільні телефони та сім-карти.

Своєрідним способом приховування злочинів щодо торгівлі людьми є використання злочинцями для вербування жертв і комунікації зі спільниками додатків-месенджерів які ускладнюють ідентифікацію співрозмовника.

Із наведеного можна зробити висновок, що спосіб вчинення злочину полягає у діях злочинця, виражених у певній послідовній системі операцій і прийомів, спрямованих на досягнення злочинної мети й охоплюють способи готування, вчинення та приховування.

Внаслідок вчинення злочинцем тих чи інших дій, спрямованих на досягнення злочинної мети, у навколишній обстановці відбуваються відповідні зміни, які прийнято називати слідами злочину та які можуть вказувати на ті чи інші обставини події, що відбулася. 
Сліди злочину в науковій літературі розглядаються у вузькому та широкому значенні. Сліди у вузькому значенні - це матеріальні утворення, що відбивають зовнішню будову взаємодіючих об'єктів, тобто сліди-копії, які можуть бути об'ємними або площинними. Сліди в широкому значенні - це будь-які зміни в навколишньому середовищі, причинно пов' язані з подією злочину. Тому слідами є: a) матеріальні предмети або їхні частини (труп, знаряддя злому, недопалок, пляма крові, порція зерна, рідини); б) матеріальні копії (слід пальця, взуття, розрубу, розрізу та ін.). Водночас слідами в широкому значенні є ідеальні відображення - сліди пам'яті (уявні образи). Вони в інформаційному плані є більш ємними і відбивають як увесь об’єкт загалом, так і його частини. Сліди пам'яті є джерелами вербальної інформації щодо форми і властивостей об'єкта, але вони суб'єктивні [9, с. 112].

До елементів слідової картини злочину А.П. Шеремет відносить:

- змінивречовійобстановцімісцяподіїзлочину. Ці зміни, відображаючи дії злочинця, потерпілого та інших осіб, дії знарядь, засобів і механізмів, полягають у порушенні початкового стану, місцезнаходження, структури різних об'єктів, що складають речове середовище, в якому вчинено злочин;

- сліди-відображення (сліди рук, ніг, інструментів тощо);

- предмети - речові докази, в т. ч. документи, речі та мікрочастини. Набір конкретних об'єктів, що виступають як речові докази, за різними видами злочинів неоднаковий;

- документи - письмові докази різного виду i призначення. Документи виконують важливі функції в різних сферах громадської, виробничої, культурної, особистої діяльності сучасного суспільства. Вони часто містять важливі для розслідування відомості;

- особи, що можуть бути допитані як свідки. Особисте сприйняття події злочину робить особу

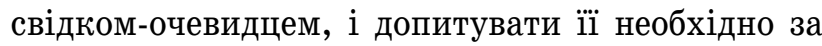
цими підставами [10, с. 344].

Типовими слідами вчинення торгівлі людьми є:

Сліди-документи. У 100\% досліджених нами випадків внаслідок вчинення злочину лишалися документи, які були використані правоохоронцями як докази у кримінальному провадженні.

Щодо слідів-документів, то, за даними О.В. Шаповала, доказового значення набувають вилучені в осіб, причетних до торгівлі людьми, трудові договори (контракти), укладені з потерпілими; боргові та інші розписки; закордонні та громадянські паспорти; копії квитанцій про міжнародні поштові відправлення; документи про надходження грошових відправлень, альбоми 3 фотографіями жертв тощо [11, с. 255].

За результатами проведеного нами аналізу слідчо-судової практики, найчастіше такими до- кументами були: проїзні документи (білети автобусного, залізничного й авіасполучення) (56\%), внутрішні та закордонні паспорти потерпілих і злочинців (84\%), грошові кошти (75\%), кредитні карти $(89 \%)$, боргові розписки $(47 \%)$, трудові договори (контракти), укладені із потерпілими $(21 \%)$, тощо.

В абсолютній більшості досліджених випадків $(95,3 \%)$ ті чи інші етапи злочинної діяльності відбувалися в умовах очевидності та залишали ідеальні відображення в пам'яті потерпілих і свідків-очевидців, які допитувалися під час досудового розслідування.

Серед речових доказів найчастіше $(93,3 \%)$ слідами злочину виступали мобільні засоби зв'язку.

Крім того, заслуговує на увагу теза О.В. Захарової та O.I. Герасимова, котрі зазначають, що невід'ємною складовою частиною підготовки, вчинення і приховування кримінальних правопорушень щодо торгівлі людьми є застосування інформаційних технологій і телекомунікаційних мереж, які сприяють збиранню інформації про потенційну жертву злочину, вербування осіб, котрі можуть бути потенційними жертвами, створення різноманітних веб-сайтів та агенцій для пошуку жертв, розміщення оголошень на електронних дошках оголошень, для комунікації членів злочинного угруповання тощо. Внаслідок таких неправомірних діянь утворюються цифрові сліди, які залишаються вінформаційномупросторі [12, с. 55].

До цифрових слідів торгівлі людьми $(91,5 \%)$ можна віднести застосунки та програми, що використовувалися злочинцями, електронні документи; збережені на носіях електронної інформації фото- та відеозображення жертв тощо.

Таким чином, типовими слідами вчинення торгівлі людьми є сліди-документи $(100 \%)$, мобільні засоби зв'язку $(93,3 \%)$, ідеальні відображення в пам'яті потерпілих і свідків-очевидців (95,3\%), цифрові сліди 91,5\% .

Як зазначає В.Ю. Шепітько, обстановка місця вчинення злочину - це частина матеріального середовища, яка включає, крім ділянки території, сукупність різних предметів, поведінку учасників події, психологічні взаємовідносини між ними. Обстановка як сукупність матеріальних об'єктів на місці злочину відбиває механізм злочинної подіï, особливості дій злочинця та інших учасників. Криміналістичні ознаки обстановки можуть мати взаємозумовлені зв'язки 3 іншими елементами криміналістичної характеристики (способом злочину, часом, місцем та ін.) [13, с. 426].

Під місцем вчинення злочину прийнято розуміти територію, інше місце, яке характеризується фізичними, соціальними та правовими критеріями, де було розпочато, продовжено чи припинено злочинне діяння [14, с. 133]. 3 погляду криміналістичної характеристики торгівлі людь- 
ми значення має як конкретне місце здійснення вербування, транспортування (переміщення) й експлуатації потерпілого, так і країна, на теритоpiї та під юрисдикцією якої було вчинено злочин.

Результати узагальнення матеріалів слідчо-судової практики за фактами торгівлі людьми показали, що у $30,8 \%$ випадків злочин вчинявся лише на території України, у 69,2\% - на території України та інших держав. Зокрема, на території України зазвичай діють особи, котрі підшукують, вербують і переміщують жертв, а на території іншої держави - особи, які організовують і фінансують торгівлюлюдьми, й особи, що експлуатуютьжертв.

Щодо країн, до яких незаконно переміщували потерпілих, то найпопулярнішими є Туреччина (35,3\%), Ізраїль (31,3\%), Об'єднані Арабські Емірати $(13,1 \%)$, Китайська Народна Республіка $(11,1 \%)$ та Російська Федерація $(9,2 \%)$.

Місцями вербування жертв найчастіше були торговельні центри, кафе та ресторани.

Висновки. Підсумовуючи викладене, слід зазначити, що використання слідчим на початковому етапі розслідування торгівлі людьми взаємозумовлених зав'язків між розглянутими та іншими елементами криміналістичної характеристики цього виду злочинів допоможуть йому у побудові слідчих версій, плануванні розслідування та вирішенні низки інших завдань. Однак такі елементи криміналістичної характеристики цього виду злочинів, як особа потерпілого й особа злочинця потребують подальшого дослідження.

\section{Jimepamypa}

1. Закон України «Про протидію торгівлі людьми. Відомості Верховної Ради Украӥни. 2012. № 19-20. Ст. 173. URL: https://zakon.rada.gov.ua/ laws/show/3739-17.

2. Кримінальний процесуальний кодекс України. Кодекс України; Закон, Кодекс від 13 квітня 2012 р. № 4651-VI / Верховна Рада України. URL: http://zakon.rada.gov.ua/laws/show/4651-17.

3. Методика розслідування окремих видів злочинів, підслідних органам внутрішніх справ : навчальний посібник / O.В. Батюк, P.І. Благута, О.М. Гумін та ін. ; за заг. ред. Є.В. Пряхіна. Львів, 2011. 324 с.

4. Черечукіна Л.В., Яковенко М.О. Виявлення та розслідування злочинів, пов'язаних 3 торгівлею людьми : методичні рекомендації. Луганськ, 2013. 135 с.

5. Никифоряк Л.П., Орлеан А.М. Аналіз судової практики з питань застосування законодавства України щодо протидії торгівлі людьми. Київ, 2018. 88 с.

6. Горбасенко П.В. Загальні положення методики розслідування торгівлі людьми : автореф. дис. ... канд. юрид. наук : 12.00. 09. Київ, 2013. 22 с.

7. Малярова В.О. Способи вчинення торгівлі людьми: питання систематизації. Вісник Луганського державного університету внутрішніх справ імені E.O. Дідоренка. 2015. № 2. С. 105-113.

8. Волкова А.І. Структура криміналістичної характеристики торгівлі людьми. Актуальні проблели держави і права. 2006. № 27. С. 174-181.

9. Салтевський М.В. Криміналістика : підручник : у 2 ч. Ч. 1. Харків, 1999. 416 с.
10. Шеремет А.П. Криміналістика : навчальний посібник. Київ, 2009. 472 с.

11. Шаповал О.В. Слідова картина торгівлі людьми. Науковий вісник Міжнародного гуманітарно20 університету. Серія : Юриспрудениія. 2014. № 8. C. 254-256.

12. Захарова О.В., Гарасимів О.І. Сліди застосування інформаційних технологій при вчиненні злочинів, пов'язаних 3 торгівлею людьми. Протидія незаконній міграцї̈ та торгівлі людьли : Мат. III міжнар. наук.-практ. симпоз. м. Івано-Франківськ, 12-13 квіт. 2019 p. C. $55-57$.

13. Криміналістика : підручник / В.Ю. Шепітько, В.О. Коновалова, В.А. Журавель та ін. ; за ред. В.Ю. Шепітька. Київ : Ін Юре, 2016. 640 с.

14. Мороз В.Г. Поняття місця вчинення злочину як ознаки об'єктивної сторони злочину. Юридична наука. 2014. № 5. C. 122-136.

\section{Анотація}

Коваленко В. В. Типові способи, сліди й обстановка вчинення злочину як елементи криміналістичної характеристики торгівлі людьми. - Стаття.

У статті на основі узагальнення спеціальної літератури та практики досудового розслідування і судового провадження за фактами торгівлі людьми розкрито сутність таких елементів криміналістичної характеристики цього виду злочинів, як типові способи, сліди й обстановка вчинення злочину.

Зазначено, що спосіб вчинення злочину полягає у діях злочинця, виражених у певній послідовній системі операцій і прийомів, які спрямовані на досягнення злочинної мети, й охоплює способи готування (підшукування спеціальних знарядь і засобів (мобільні телефони, месенджери для зв'язку із жертвою та спільниками, транспортні засоби для транспортування жертви тощо), досягнення незаконної угоди із контрагентом щодо людини; підшукування жертв злочину в мережі інтернет тощо); вчинення (умовляння або примушування жертви; переміщення жертви; експлуатація жертви) та приховування (використання підроблених документів; повідомлення вербованим особам неправдивих відомостей про себе; використання спеціально придбаних одноразових мобільних телефонів і сім-карт тощо).

Визначено, що типовими слідами вчинення торгівлі людьми є: сліди-документи, (трудові договори (контракти), укладені з потерпілими, проїзні документи (білети автобусного, залізничного й авіасполучення), паспорти потерпілих і злочинців, грошові знаки, кредитні карти, розписки тощо); відображення інформації про подію злочину в пам'яті свідків-очевидців, котрі допитувалися під час досудового розслідування (ідеальні сліди); речові докази (мобільні засоби зв'язку); цифрові сліди (застосунки та програми, що використовувалися злочинцями, електронні документи; збережені на носіях електронної інформації, фотота відеозображення жертв тощо).

Доведено, що з погляду криміналістичної характеристики торгівлі людьми значення має як конкретне місце здійснення вербування, транспортування (переміщення) й експлуатації потерпілого, так і країна, на території та під юрисдикцією якої було вчинено злочин.

Криміналістичні ознаки обстановки місця вчинення торгівлі людьми мають взаємозумовлені зв'язки 3 іншими елементами криміналістичної характеристики цього виду злочинів, що має враховуватися слідчими під час висунення версій і планування розслідування на початковому його етапі.

Ключові слова: торгівля людьми, криміналістична методика, криміналістична характеристика, елементи 
криміналістичної характеристики, типові способи, типові сліди, типова обстановка.

\section{Summary}

Kovalenko $V$. V. Typical methods, traces and circumstances as elements of criminal characteristics of human trafficking. - Article.

The article, based on the generalization of special literature and practice of pre-trial investigation and court proceedings on human trafficking, reveals the essence of such elements of forensic characteristics of this type of crime as typical methods, traces and circumstances of the crime.

It is stated that the method of committing such crime consists in the actions of the offender, expressed in a consistent system of operations and techniques aimed at achieving the criminal goal and includes methods of preparation (search for special tools and means (mobile phones, messengers to communicate with victims and accomplices, vehicles for transporting the victim, etc.), reaching an illegal agreement with a counterparty; searching for victims of crime on the Internet, etc.); committing (persuading or coercing the victim; moving the victim; exploiting the victim) and concealment (use of forged documents; informing recruits of false information about themselves; use of specially purchased disposable mobile phones and SIM cards, etc.).
It is determined that typical traces of human trafficking are: traces-documents (employment agreements (contracts) concluded with victims, travel documents (bus and air tickets), passports of victims and criminals, banknotes, credit cards, receipts, etc.); display of information about the crime in the memory of eyewitnesses who were interrogated during the pre-trial investigation (ideal traces); physical evidence (mobile means of communication); digital traces (applications and programs used by criminals, electronic documents; photos and videos of victims stored on electronic media, etc.).

It is proved that from the point of view of forensic characteristics of human trafficking, the specific place of recruitment, transportation (movement) and exploitation of the victim, as well as the country in the territory and jurisdiction of which the crime was committed, are important.

Forensic features of the trafficking situation have interdependent links with other elements of the forensic characterization of this type of crime, which should be taken into account by investigators when proposing versions and planning an investigation at its initial stage.

Key words: human trafficking, forensic methods, forensic characteristics, elements of forensic characteristics, typical methods, typical traces, typical situation. 